\title{
VERPLEGING VAN DIE GEESTESVERTRAAGDE KIND
} IN DIE GEMEENSKAP

\section{S.J. MOOLMAN}

\section{INLEIDING}

Wanneer ons hoor van Verpleging van die Kind is ons geneig om slegs aan die fisiese versorging van 'n siek kind te dink. Voordat 'n mens egter nie self te doene gekry het met die geestesvertraagde kind nie, besef jy nie dat ons hier met "n eiesoortige verpleegsorg te make het nie. Dit beteken nie dat ons hier die termometer en hoesstropie nooit gebruik nie, inteendeel, die geestesvertraagde kind het soms ook die gewone mediese verpleegsory nodig, maar by sy sorg is daar ' $n$ besliste klemverskuiwing.

Om 'n wetenskaplike benadering tot die geestesvertraagde kind se verpleegsorg te hê sal verseker dat daar op 'n ordelike, sistematiese manier te werk gegaan word sonder dat belangrike aspekte oor die hoof gesien word.

\section{OPSPORING EN EVALUASIE}

Alvorens die verpleegkundige van enige nut kan wees moet hierdie geestesvertraagde kind opgespoor word. Daar is die gewone manier van identifikasie deur die kraamsuster reeds in die kraamsaal, soos in die geval van 'n baba met Down's sindroom. By kretinisme, wat selde voor die ouderdom van ses weke opgespoor word, kom dit in die eerste plek onder die aandag van die gemeenskapsverpleegkundige byvoorbeeld by die immunisasiekliniek.

\section{SUMMARY}

There is a shift in emphasis in nursing care of the mentally retarded child in the community. Firstly, the child must be identified and then his condition is evaluated, usually by a multi-disciplinary team. A decision must then be made whether the child will be cared for in the community.

The nurse assists the parent or guardian in training for independence which includes self-care, use of toilet, personal hygiene, and dressing. Training in various perceptual and motor skills are also included in the nursing care plan.

The nurse makes follow-up visits to evaluate progress and adapts the nursing care plan as necessary. She also has an important role in encouraging and guiding the parents. Nursing the mentally retarded child in the community requires specialised knowledge - and a lot of love.

Ná identifikasie word die kind deeglik geëvalueer. Dit sluit ook 'n mediese ondersoek in, om fisiese faktore soos doofheid en blindheid uit te skakel.

In hierdie artikel sal die skrywer soms verwys na Jakkie, die kleuter met geestesvertraagdheid van idiopatiese oorsprong. Hy is reeds as baba deur sy ouers verwerp en word deur Mev X, sy ouma, versorg.

Sy evaluasie is gedoen deur 'n multidissiplinêre span. Die verpleegkundige kan ook 'n aanvullende evaluasie doen van die algemene gedrag van die kind. Hier is dit goed om die kind tuis en by sy gesin in sy eie omgewing te sien, waar hy meer ontspanne is. Waarneming van interaksie tussen die kind en die res van die gesin word gedoen. Die volle samewerking en vertroue van die ouers, in hierdie geval Mev X, sal ons taak vorentoe vergemaklik.

Nooit moet ons die waarde van speelgoed onderskat nie. By evaluasie en dwarsdeur ons verpleegsorgplan bly speel en speelgoed van onskatbare waarde as hulpmiddel. Nie net waarméé die kind speel is van belang nie, maar ook hoe hy speel. Word die speelding gebruik waarvoor dit bedoel is? Hier dink ons aan die outistiese kind wat byvoorbeeld sy driewiel op die sy sal gooi en dan vir ' $n$ abnormale lang tydperk 'n wiel sal draai en draai terwyl hy skynbaar totaal onbewus is van wat om hom aangaan.

Die ontwikkelingsmylpale van die kind dien ook as indikasie by evaluasie - wanneer die kind begin kruip en loop het; begin praat het: toiletselfstandigheid en so meer. Hierdie inligting asook die mediese geskiedenis van die kind word normaalweg van die moeder verkry.

Daar is verskeie hulpmiddels by die vasstel van die kind se verstandsouderdom soos die Washington Gids en die Gunzburgtoetse.

Reeds tydens die evaluasie-stadium is ' $n$ vertrouensverhouding tussen Mev X en my, as psigiatriese verpleegkundige, opgebou. Dit het sake vergemaklik en tot Jakkie se voordeel gestrek. 


\section{JAKKIE SE VERSORGING}

Die graad van ' $n$ kind se gestremdheid voorspel die tempo van sy verstandelike groei en bepaal . . sy uiteindelike grens (Blodgett, p24). Dit kon die skrywer ten beste aan Mev $\mathrm{X}$ verduidelik op die nie-tegniese wyse van dokter Blodgett wat 'n talentvolle kind vergelyk met 'n straalvliegtuig, 'n normale kind met 'n skroefaangedrewe vliegtuig. 'n opvoedbare gestremde kind met 'n passasierstrein en die opleibare gestremde kind met 'n goederetrein.

Mev $X$ het by ons bevinding berus en het ons meegedeel van haar besluit om aanvanklik vir Jakkie tuis te versorg totdat hy skoolgaande ouderdom bereik en na 'n opleidingsentrum kan gaan. Sy was egter baie onseker oor hoe om hom te versorg en wou weet hoe sy as leek tot sy ontwikkeling en opleiding kon bydra. Daar die skrywer sedert ons ontmoeting ook onbewustelik vir háár as voog geëvalueer het, het sy die volste vertroue gehad dat Mev X bevoeg is om as moeder in te staan en om aan Jakkie die liefdevolle versorging te gee wat hy nodig het. Hierdie moederfiguur is onontbeerlik vir die geestesvertraagde kind se psigososiale ontwikkeling.

Ná deeglike oorweging het die span tot die slotsom gekom dat Jakkie tuis gekonsentreerde aandag sal ontvang aangesien Mev X heeldag tuis was en geen ander afhanklikes gehad het wat haar aandag vereis nie.

Verder was daar genoeg natuurlike stimulasie in sy daaglikse omgewing, soos sy kontak met troeteldiere en luister na die musiek oor die radio.

Dit het geblyk dat die band wat reeds tussen hierdie relatiewe jong ouma en haar gestremde kleinkind ontstaan het, sterk genoeg is om stresstydperke te oorleef sonder letsels aan enigeen van die twee betrokkenes. Mev X het reeds Jakkie se nieverbale kommunikasie begryp en die maniertjies wat eie aan hom as individu is, soos om aan sy teddiebeer se oor te suig as hy vaak is.

Mev X het egter leiding nodig gehad en daarom het ek vir Jakkie 'n verpleegsorgplan uitgewerk. Die oorkoepelende doelstellings van so 'n program is selfsorg, onafhanklikheid, om sy optimum potensiaal te bereik en om in die gemeenskap aanvaarbaar te wees.

\section{OPLEIDING TOT ONAFHANKLIKHEID}

'n Normale kind leer amper outomaties om sy basiese behoeftes te beheer en te hanteer. Die gestremde kind het opleiding en hulp nodig om onafhanklik te wees. Vir laasgenoemde sal dit langer neem om te leer en meer herhaling is nodig. 'n Roetine moet ingestel word byvoorbeeld om hande voor etes en na toiletgebruik te was. Die kind moet beloon word as hy iets reggekry het - dikwels is 'n omhelsing of drukkie genoeg.

\section{Selfsorg}

Hier is dit belangrik dat die kind eers die maklikste takies en geleidelik die moeiliker take aanleer. Die leersituasie kan vir ouer en kind pret wees. Dit is noodsaaklik dat die gestremde sover moontlik leer om wat persoonlike higiëne en versorging betref, selfstandig te wees want dit maak die kind meer aanvaarbaar in die gemeenskap (Marsh).

\section{Eetgewoontes}

Baie geduld word geverg voordat die gestremde kind onafhanklik kan eet. Stap vir stap word die kind geleer om eers met sy hande, later met 'n lepel en nóg later met 'n mes en vurk te eet. So gou moontlik moet hierdie kind saam met die gesin eet. Nie net omdat die res van die gesin as rolmodel dien nie maar ook omdat 'n maaltyd 'n sosiale aktiwiteit is.

\section{Toiletgebruik}

Verstandelik gestremde kinders leer derm en blaasbeheer stadiger en op 'n later stadium as normale kinders. Hier is 'n kalm optrede en 'n vaste roetine die kerngedagtes. Die gestremde kind sal later, net soos die normale kind, 'n definitiewe patroon by toiletgebruik volg.

Klere speel 'n belangrike rol by toilet-onafhanklikheid. Broekies met ' $n$ rek of ritssluiter is makliker hanteerbaar as 'n band met knope en ingewikkelde gespes. Moenie u ontsteltenis op die kind oordra as hy 'n glipsie gehad het nie. Beloon egter mildelik as hy suksesvol was.

\section{Persoonlike higiëne}

Die kind se houding oor higiëne sal in 'n groot mate afhang van die wyse waarop die kennismaking daarmee geskied het. Selfs normale kinders is dikwels traag om tande te borsel of agter hul ore te was. Laat ons dus nog meer geduldig wees met die gestremde kind en eenvoudige metodes geleidelik aan hom oordra.

\section{Uit- en aantrek}

Dit is dikwels makliker en vinniger vir die ouer om self die kind uit en aan te trek. Maar so 'n kind kan nie leer om onafhanklik te wees nie. Dit is makliker om uit as aan te trek. Moet weereens nie klere met ingewikkelde vasmaakmetodes gebruik nie - dit ontmoedig die kind. Beloon elke poging dadelik. Aanvanklik kan die moeder al die stappe doen en slegs die laaste stap vir die kind los. Laat hom in die begin ten minste self probeer en verminder geleidelik die hulp totdat hy homself kan help.

\section{Vaardigheidsontwikkeling}

By die opstel van 'n program vir Jakkie se perseptueel-motoriese vaardighede het die skrywer waardevolle leiding gekry uit L.R. Uys se boek Psigiatriese verpleging van die geestesvertraagde. Allereers moet die kind balanseer-aktiwiteite kan baasraak. Dit kan speel-speel geskied. So is Jakkie se aandag op 'n ooievaar gevestig tydens 'n uitstappie na die dieretuin. $\mathrm{Na}$ vele oefening kon hy ook soos die ooievaar op een voet staan met die sool van sy ander voet teen die binnekant van sy knie. Op hierdie manier kan verskeie aspekte van die geestesvertraagde kind se opleiding ineengeweef word.

Die tweede aktiwiteit na balansering is voortbeweging. Dit is basiese bewegingsvaardighede soos loop, hardloop en spring wat later opgevolg word met aan-aan speletjies. Oefening wat beweging en ritme behels kon in Jakkie se geval ongemerk geskied deur sy besondere voorliefde vir musiek.

By die inweef van kontakvaardighede in sy daaglikse program is van tuisgemaakte klei gebruik gemaak. 
Hy het ook 'n kleurvolle versameling boudoppe - die deksels van sproeikannetjies - gehad. Alle speelgoed moet in helder kleure wees om die kind se aandag te trek. Krale inryg was een van die handvaardighede wat Jakkie intens gefrustreer het en daarom is dit tydelik van sy program afgehaal tot tyd en wyl sy fyn motoriese bewegings verbeter het. Take wat bo die kind se vermoëns is ontmoedig hom.

Met fisiese fiksheid in gedagte is tyd ingeruim vir balspeletjies en oefeninge waardeur gewrigsbeweegbaarheid bevorder word. Mev X is aangemoedig om van die bure se kinders saam met Jakkie te laat speel omdat dit noodsaaklik is vir sy sosiale ontwikkeling en terselfdertyd fisiese oefening bied. Dikwels word hierdie kinders in isolasie groot omdat die ouers of skaam is omdat hul kind anders is, of omdat hulle oorbeskermend teenoor die kind is

\section{Normaliseringsbeginsel}

By die verpleegsorg van die geestesvertraagde kind is dit belangrik om die Normaliseringsbeginsel te volg. Hierdie beginsel het sy ontstaan in Swede gehad en beteken dat die geestesvertraagde so na as moontlik aan normaal moet lewe. Hierdie beginsel kan toegepas word op al drie die basiese aktiwiteitsareas, naamlik selfsorg, arbeid en ontspanning. Ook wat hierdie kinders se klere betref geld die normaliseringsbeginsel.

Jakkie is aangetrek soos enige ander normale seuntjie van sy ouderdom. Sy BMX-T-hempie het hy nie met ' $n$ fiets vereenselwig nie, maar hy was soos enige ander kleuter betower met die helder kleure daarvan. Ons het Jakkie voor die spieël laat paradeer en sy ouma het nie handboekkennis nodig gehad om te weet dat dit sy selfbeeld verhoog nie.

\section{OPVOLGBESOEKE}

Net soos die kind wat in 'n inrigting versorg word, word die kind wat tuis versorg word ook voortdurend geëvalueer. Die verpleegsorgprogram word dan indien nodig gewysig en aangepas.
Aangesien die kind wat in die gemeenskap versorg word die meeste van sy tyd saam met die ouer deurbring is noue samewerking tussen die verpleegkundige en die ouer noodsaaklik. Tydens konsultasie bied die verpleegkundige aan die ouers die geleentheid om hul vrese, kommer en probleme te bespreek. Sy luister aandagtig en raak ook later daarop ingestel om dic nicverbale boodskappe op te vang, en bied emosionele ondersteuning. Sy gee raad en leiding oor opleiding en dissiplinering van die kind. Sy bring dit onder die ouer se aandag dat die hoeveelheid onathanklike funksionering van hierdie kind sal afhang van sy graad van geestesvertraagdheid, die opleiding wat hy ontvang, asook volgehoue stimulasie.

Die verpleegkundige wat tydens haar tuisbesoek entoesiasties is omtrent die opleiding en die vordering wat gemaak is, sal vind dat haar entoesiasme aansteeklik is. Haar opregte belangstelling motiveer ouer én kind.

\section{Ouergroepe}

Op die aanbeveling van die skrywer het Jakkie se ouma hom nou en dan by 'n baba-oppasser gelaat sodat sy ouergroepe kon bywoon. By sulke ouergroepe word sake van gemeenskaplike belang deur die ouers bespreek. Soms word ouers deur 'n professionele persoon, soos in kliniese sielkundige of 'n psigiatriese verpleegkundige, toegespreek. Van die onderwerpe wat van onskatbare waarde was vir Mev $\mathrm{X}$ was:

- die emosionele behoeftes van die geestesvertraagde: naamlik aanvaarding, dat hul iets beteken, en dat ander mense van hulle hou.

- stimulering en onderrig van die geestesvertraagde kind - tien goue gedagtes.

\section{TIEN GOUE GEDAGTES}

- Die geestesvertraagde kind leer op dieselfde wyse as 'n normale kind. Sy leervermoë is net stadiger vanweë sy laer intelligensie en hy het meer motivering nodig.

- Hierdie kind het ' $n$ beperkte aandagspan en aktiwiteite moet na gelang van konsentrasie afgewissel word.
- Moenie ongeduldig raak nie dan raak die kind angstig.

- Moenie oorbeskermend wees nie en moenie die kind bejammer nie.

- Moenie dinge van die kind verwag waartoe hy nie in staat is nie. Dit verhoog angs en span ning.

- Dissipline bied sekuriteit en sekuriteit is noodaaklik vir 'n stabiele persoonlikheid.

- Prys die kind wanneer hy dit verdien.

- Prestasie moet direk beloon word.

- Maak gebruik van demonstrasie saam met instruksie. Die kind leer deur nabootsing.

- Herhaling is die sleutelwoord by onderrig van die gestremde kind.

\section{SLOT}

Van alle vorms van kindergestremd. hede is verstandelike gestremdheid seker die moeilikste vir die ouer om te aanvaar en te verwerk (Steenkamp)

Die verpleging van die geestesvertraagde kind in die gemeenskap verg gespesialiseerde kundigheid omdat die ouer én kind verpleeg word - asook 'n ruim dosis liefde.

Die psigiatriese verpleegkundige se pasiëntjies word nooit gesond nie.

As hulle egter gelukkige kinders is wie se intelligensie tot maksimale potensiaal ontwikkel is en as hulle sosiaal aanvaarbaar is in die gemeenskap, het die verpleegkundige in haar doel geslaag.

\section{BIBLIOGRAFIE}

BAUMGARTNER, B. (196(1) Helping the trainable men tally resarded chitd. New York. Bureau of Publications BLODGETT. E. (1973) Verstandelik gestremde kinders Kaapstad. Tafelberg.

MARSH. J. (1984) Help sour mentally refarded child. Pretoria. Department of Health and Welfare

STEENKAMP. E. STEENKAMP. W (1979) Die verstm delik gestremde kind. Durban Butterworth

UYS. L.R. (1978) Psigiatriese verpleging van die geestesver. traagde. Bloemfontein. P.J. de Villiers.

VLOK. MARIE E. (1980) Mamual of Communin Henhi for Nurses. Cape Town. Juta. 